\title{
Global distribution of nearshore slopes with implications for coastal retreat
}

\author{
Panagiotis Athanasiou $^{1,2}$, Ap van Dongeren ${ }^{1,5}$, Alessio Giardino ${ }^{1}$, Michalis Vousdoukas ${ }^{3,4}$, \\ Sandra Gaytan-Aguilar ${ }^{1}$, and Roshanka Ranasinghe ${ }^{5,2,1}$ \\ ${ }^{1}$ Deltares, Delft, the Netherlands \\ ${ }^{2}$ Water Engineering and Management, Faculty of Engineering Technology, \\ University of Twente, Enschede, the Netherlands \\ ${ }^{3}$ European Commission, Joint Research Centre (JRC), Ispra, Italy \\ ${ }^{4}$ Department of Marine Sciences, University of the Aegean, Mytilene, Greece \\ ${ }^{5}$ IHE Delft Institute for Water Education, Delft, the Netherlands \\ Correspondence: Panagiotis Athanasiou (panos.athanasiou@ deltares.nl)
}

Received: 3 May 2019 - Discussion started: 27 May 2019

Revised: 21 August 2019 - Accepted: 2 September 2019 - Published: 2 October 2019

\begin{abstract}
Nearshore slope, defined as the cross-shore gradient of the subaqueous profile, is an important input parameter which affects hydrodynamic and morphological coastal processes. It is used in both local and largescale coastal investigations. However, due to unavailability of data, most studies, especially those that focus on continental or global scales, have historically adopted a uniform nearshore slope. This simplifying assumption could however have far-reaching implications for predictions/projections thus obtained. Here, we present the first global dataset of nearshore slopes with a resolution of $1 \mathrm{~km}$ at almost 620000 points along the global coastline. To this end, coastal profiles were constructed using global topo-bathymetric datasets. The results show that the nearshore slopes vary substantially around the world. An assessment of coastline recession driven by sea level rise (SLR) (for an arbitrary $0.5 \mathrm{~m}$ SLR) with a globally uniform coastal slope of $1: 100$, as carried out in previous studies, and with the spatially variable coastal slopes computed herein shows that, on average, the former approach would underestimate coastline recession by about $40 \%$, albeit with significant spatial variation. The final dataset has been made publicly available at https://doi.org/10.4121/uuid:a8297dcd-c34e-4e6d-bf669fb8913d983d (Athanasiou, 2019).
\end{abstract}

\section{Introduction}

A total of $10 \%$ of the world's population lives in low-lying coastal areas, i.e., less than $10 \mathrm{~m}$ above the current mean sea level (MSL) (McGranahan et al., 2007). In the future, the population density in these areas is expected to increase even more due to high rates of population growth and urbanization (Neumann et al., 2015). At the same time, coastal areas are exposed to a number of marine hazards that can lead to flooding or erosion. As the coastline comprises various different landforms (e.g., sandy coasts, rocky cliffs) and land uses (e.g., heavily urbanized or natural), the response to these hazards can vary significantly both spatially and temporally. One of the most vulnerable coastal types is sandy coasts, which are highly dynamic and can change in response to extreme marine events (McCall et al., 2010), long-term trends in MSL (Zhang et al., 2004), natural gradients in alongshore sediment transport (Antolínez et al., 2018), or human interventions (Giardino et al., 2018a; Luijendijk et al., 2018; Mentaschi et al., 2018).

Local, regional, or global studies that seek to quantify natural or human-induced coastal change require high-quality nearshore bathymetry and subaerial topography data. However, as such data are rarely available, previous studies, especially at the regional or global scale, have had to rely on a number of limiting assumptions, such as globally uniform nearshore or beach slopes (Hinkel et al., 2013; Melet et al., 2018). The nearshore area is here defined as the part of the 
cross-shore profile between the depth of closure $d_{\mathrm{c}}$ (i.e., the depth seaward of which there is no significant change in bottom elevation) and the shoreline (MSL). The nearshore slope (the ratio of the $d_{\mathrm{c}}$ over the horizontal distance between the $d_{\mathrm{c}}$ and the shoreline) modulates the wave transformation (Battjes, 1974) and the total water levels (Serafin et al., 2019), while it is associated with geomorphological processes at various temporal scales (Bruun, 1962; Wright and Short, 1984; Dean, 1991). Therefore, a global assumption of uniform slope likely hides the spatial variability of coastal hydro- and morphodynamics.

Accurate information on the offshore limit of the nearshore area (i.e., the depth of closure $d_{\mathrm{c}}$ ) and the nearshore slope is important for numerous coastal engineering applications. For example, when behavior-oriented models are employed, the depth of closure and the nearshore slope are crucial model inputs (Larson et al., 2004; Ruggiero et al., 2010; Hanson, 2014). At data-poor locations, when bathymetric data are not available, an equilibrium bathymetric profile (Dean, 1991) is often assumed and the local $d_{\mathrm{c}}$ is needed to define the offshore profile limit (Udo and Takeda, 2017). Various assessments of future coastal recession due to sea level rise (SLR) have used the Bruun rule (Bruun, 1962) to quantify coastal retreat (Zhang et al., 2004; Hinkel et al., 2013; Baron et al., 2014; Monioudi et al., 2017; Udo and Takeda, 2017; Ballesteros et al., 2018; Giardino et al., 2018b), an approach which is very sensitive to the nearshore slope. The most common approach to estimate $d_{\mathrm{c}}$ is using empirical formulae (Hallermeier, 1978; Birkemeier, 1985; Nicholls et al., 1998) that relate $d_{\mathrm{c}}$ to wave parameters. This has been employed in several studies at both the global scale (Hinkel et al., 2013) and regional scale (Brutsché et al., 2016; Toimil et al., 2017).

Against the foregoing background, the present study sets out to provide the first ever global database of nearshore slopes and their associated depths of closure, which can be used in local, regional, or global studies which aim to quantify coastal response to natural (i.e., marine extremes and climate change) or human-induced phenomena. Our methods utilize available open-source global datasets of topography, bathymetry, and shoreline location in order to create a seamless representation of coastal morphology. Furthermore, global wave statistics are used to estimate $d_{\mathrm{c}}$. The resulting dataset consists of an estimation of the local nearshore slopes at $\sim 620000$ points along the global coastline.

This paper is structured as follows: Sect. 2 describes the methods used for the creation of the seamless coastal morphology map, the calculation of the global depths of closure, the definition of the coastal profiles, and the calculation of the nearshore slopes. Section 3 presents the results of the analysis, consisting of a global dataset of depths of closure and nearshore slopes while Sect. 4 compares the results versus observed data at several locations around the world. The paper concludes with a discussion of key points, including a global analysis of the sensitivity of coastal recession esti- mates using the Bruun rule to the nearshore slopes, and the main conclusions.

\section{Materials and methods}

\subsection{Workflow to obtain nearshore slopes}

The estimation of nearshore slope required the following steps (Fig. 1). First, a seamless topo-bathymetric map was created (Sect. 2.2.1), and then cross-shore transects were drawn with an accompanying elevation profile (Sect. 2.2.2). Using global wave data the depths of closure were determined (Sect. 2.3), after which the nearshore slopes could be determined (Sect. 2.4).

\subsection{Coastal profiles}

\subsubsection{Global topo-bathymetric data}

A cross-shore contiguous representation of the coastal profile is needed in order to accurately derive geometrical parameters such as the nearshore slope. Presently, elevation data are separated between topographic, i.e., representing the subaerial surface of the Earth, and bathymetric, i.e., representing the subaqueous seabed. Here we merge two of these datasets in order to create a seamless elevation layer with a smooth transition between land and water.

The topographic layer that was used is the MERIT digital elevation model (DEM) (Yamazaki et al., 2017), which is an improved version of the existing spaceborne DEMs SRTM3 v2.1 (Farr et al., 2007) and AW3D-30m v1 (Tadono et al., 2015), after removing multiple error components (i.e., absolute bias, stripe noise, speckle noise, and tree height bias). It represents the terrain elevations at a 3 arcsec resolution ( $\sim 90 \mathrm{~m}$ at the Equator) and covers land areas between $90^{\circ} \mathrm{N}$ and $60^{\circ} \mathrm{S}$, referenced to the EGM96 geoid. The bathymetric layer was obtained from the General Bathymetric Chart of the Oceans (https://www.gebco.net, last access: 15 September 2018), which is based on ship track soundings with interpolation between soundings guided by satellite-derived gravity data. The version used was the GEBCO_2014 Grid (Weatherall et al., 2015), which has a 30 arcsec resolution ( $\sim 900 \mathrm{~m}$ at the Equator) and it is generated by the aggregation of heterogeneous data types assuming all of them to be referred to MSL.

As the two datasets might overlap, the Open Street Map (OSM) (OpenStreetMap contributors, 2015) coastline was used to create a mask for land and water. For the final elevation dataset, a common grid was used, with a resolution corresponding to the higher resolution of the MERIT DEM dataset. Subsequently, the bathymetric data were interpolated only at the cells seaward of the OSM coastline. This was performed by a linear interpolation of the values at neighboring grid points in the $x$ and $y$ dimensions. One of the key elements when merging bathymetry and elevation data is to create a smooth transition between land and water. We 


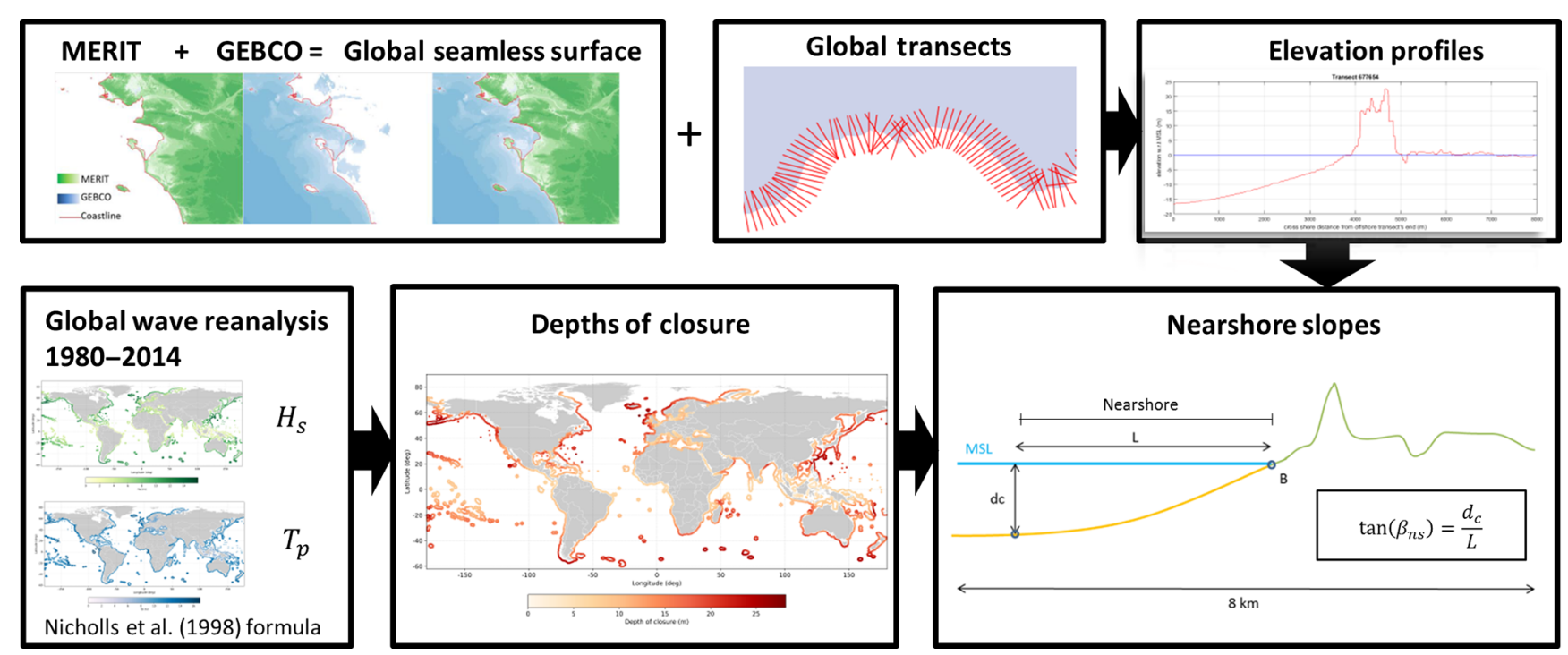

Figure 1. Work flow followed for the calculation of the nearshore slopes worldwide.

have applied a low-pass filter to decrease disparities between pixel values by averaging nearby pixels. The smoothing technique was applied only on the cells along the coastline. For each cell the vertical offset $\Delta z$ was computed (as the difference in elevation with respect to its neighboring cell). For the smoothing procedure different windows (i.e., number of grid cells around the grid cell to be smoothed) were used according to $\Delta z$. Smoothing window sizes of $3 \times 3$ were applied at areas where $\Delta z$ was up to $10 \mathrm{~m}, 5 \times 5$ grid cells where $\Delta z$ was higher than $10 \mathrm{~m}$, and $9 \times 9$ in a few geographic areas where topography data present a big discrepancy with respect to the bathymetry.

\subsubsection{Global elevation transects}

The global coastline was defined using the OSM dataset of 2016. Since the full-scale coastline was found to be too detailed for the purposes of the present work, the level 8 generalized version of the dataset was used, which is a smoothed version that removes small details and has been previously used in global coastal assessments (Luijendijk et al., 2018). About 1000000 cross-shore transects were defined along the OSM coastline, spaced at $1 \mathrm{~km}$ intervals. To ensure a globally consistent spacing and length of the transects, the coastline was re-projected to the local UTM projection, before creating the transects. The middle point of each transect was defined at the OSM location, with a $4 \mathrm{~km}$ extension in both the landward and seaward directions. The profile length was chosen after testing different lengths to ensure that the active coastal profile is captured while minimizing data storage. The $1 \mathrm{~km}$ spacing was chosen in order to have a good coverage of the alongshore variability of the coastal profiles, while keeping the computational costs at a feasible level. Along each transect, a set of equidistant points was defined at an interval of
$25 \mathrm{~m}$, while flagging the locations where the elevation values were extracted from the global grid. For each transect the longitude and latitude of the extraction points were used to sample from the global merged elevation grid and create a continuous elevation profile.

The global transects $(\sim 1000000)$ were first filtered to exclude transects located along coasts covered with ice, river inlets, or major ports, using the global transects of Luijendijk et al. (2018). This reduced the total number of transects to about 780000 transects. Additionally, and specifically for the application described in Sect. 4.2, the sandy beach location data from Luijendijk et al. (2018) were used in order to identify the transects that were sandy, resulting in about 215000 sandy transects. Note that gravel beaches are included in this dataset and are herein referred to as sandy.

\subsection{Calculation of the depth of closure}

The depth of closure was calculated using the formulation of Nicholls et al. (1998):

$d_{\mathrm{c}}=2.28 H_{\mathrm{e}, t}-68.5\left(\frac{H_{\mathrm{e}, t}^{2}}{g T_{\mathrm{e}, t}^{2}}\right)$,

where $H_{\mathrm{e}, t}$ is the significant wave height that is exceeded only $12 \mathrm{~h}$ per $t$ years, $T_{\mathrm{e}, t}$ is the associated wave period, and $g$ is the gravitational acceleration. The selection of the length of the time series $t$ in this formula is directly associated with the temporal scale of the application of the depth of closure. This means that, for example, applications that consider temporal scales on the order of decades (i.e., coastline models, Bruun rule) should use a $t$ that is consistent with the assessment scale. Naturally, the temporal extent of the time series is dictated by the length of the available observations or modeling results. For example, Udo and Takeda (2017) applied 
Eq. (1) for SLR-induced coastal recession assessments along the Japanese coast taking into account the effects of timescale for their 100-year Bruun rule application by using the maximum wave heights in their 5-year-long wave record.

Here we applied Eq. (1) using the full time series of significant wave heights $H_{\mathrm{s}}$ and peak wave periods $T_{\mathrm{p}}$ from the global reanalysis covering the period between 1980 and 2014 presented by Vousdoukas et al. (2017). Waves were simulated using the third-generation spectral wave model WW3. The model has been extensively validated and detailed information can be found in the reference provided. The wave parameters were available every $3 \mathrm{~h}$ at offshore locations covering the ice-free coasts. Following Nicholls et al. (1998) here we calculate $H_{\mathrm{e}, t}$ as the wave height that is not exceeded more than $12 \mathrm{~h}$ over the full 34 -year time series. This approach is expected to lead to larger $d_{\mathrm{c}}$ values than taking the yearly statistics, as larger waves will be included in the time series.

\subsection{Estimation of the nearshore slope}

For each of the transects, the cross-shore location of the depth of closure $d_{\mathrm{c}}$ was identified using the elevation profile and the $d_{\mathrm{c}}$ value derived as described in this section. The location of the depth of closure was calculated by finding the first (i.e., moving from the most offshore point towards land) point, which was shallower than the $d_{\mathrm{c}}$ and then linearly interpolating in between the adjacent cross-shore points along the transect. Then the cross-shore location of the shoreline (MSL) point was estimated using a similar method. In case of multiple shoreline points (e.g., barrier islands) the point that was located closer to the OSM defined point was chosen. The cross-shore distance between these two points was used as the horizontal length of the nearshore area $L$. The nearshore slope $\tan \left(\beta_{\mathrm{ns}}\right)$ was then calculated as the ratio $\frac{d_{\mathrm{c}}}{L}$.

At locations in which the calculation could not be carried out as described above, an error code was assigned to describe the cause of the calculation failure (Figs. S1-S2 in the Supplement). For example, as the OSM coastline does not represent the open coast only, but includes a substantial number of areas with elevation that is far from the conventional profile presented in Fig. 1, the calculation of the slope in this way was not always successful. This was typically the case for coastlines dominated by fjord features (e.g., Norway, Chile). Furthermore, some transects did not have any offshore point in close proximity for the calculation of the depth of closure. The transects of which the nearshore slope could not be calculated were about 160000 of the total 780000 . Almost $20 \%$ out of these 160000 transects were identified as sandy.

At some other locations (mostly embayed or protected areas) the depth of closure point was located seaward of the most offshore profile point. Therefore, the deepest point was taken as the depth of closure $d_{\mathrm{c}}$. Additionally, due to the merging process of the bathymetric and topographic eleva- tion data, elevation steps close to the shoreline were observed in some transects. These transects were determined by identifying abrupt changes of the slope close to the shoreline. A warning code was also assigned to such transects (Figs. S1S2).

\section{Results}

\subsection{Global depths of closure}

The resulting global distribution of $d_{\mathrm{c}}$ (Fig. 2) showed that on open-ocean coasts, $d_{\mathrm{c}}$ generally increased with latitude because of the wave height, while $d_{\mathrm{c}}$ was smaller along the shores of more wave-sheltered seas. The global average value of $d_{\mathrm{c}}$ was approximately $13 \mathrm{~m}$, while it reached values of more than $20 \mathrm{~m}$ at some areas at higher latitudes (Fig. 3).

\subsection{Nearshore slopes}

The calculated nearshore slopes (Athanasiou, 2019) showed high spatial variability globally (Fig. 4 with continental zooms in Figs. S3-S8). The histogram of the calculated nearshore slopes (Fig. 5a) revealed that the most commonly computed nearshore slopes were around 0.005. Additionally, there was a high probability of occurrence of nearshore slopes larger than 0.2 due to the high number of transects at fjords and other steep coastlines. Furthermore, we detected several mildly sloping locations (i.e., nearshore slope lower than 0.002). Such mildly sloping coastlines are mostly characterized by high tidal range and/or muddy coastlines (e.g, northwest Australia). The median nearshore slope worldwide was 0.007, while the 10th and 90th percentiles were 0.001 and 0.565 , respectively (Fig. 5b). When only the sandy transects were considered (see Sect. 2.2.2), the most common nearshore slope shifted to 0.01 , which corresponds with the globally uniform profile slope assumed in previous globalscale studies (Hinkel et al., 2013).

The nearshore slope value is dependent on various geological and hydrodynamic factors, such as wave characteristics, sediment size, sediment supply, and large-scale geological and tectonic processes, among others. For that reason we aggregated the nearshore slopes along various regions around the world, defined heuristically considering geographical proximity and their corresponding oceans or seas. A distinct variation in the nearshore slopes can be seen among regions (Fig. 6). The three regions with the on average steeper slopes were the Pacific Islands, the Norwegian Sea, and the Mediterranean Sea with median values of 0.025 , 0.020 , and 0.014 , respectively. On the other hand, the three regions with the mildest nearshore slopes were northern Australia, the eastern US, and the Gulf of Mexico and Southeast Asia with median values of $0.001,0.002$, and 0.003 , respectively. The variance of the aggregated nearshore slopes per region (defined as the logarithmic difference between the 5th and 95th percentile) varied, with western South America and 

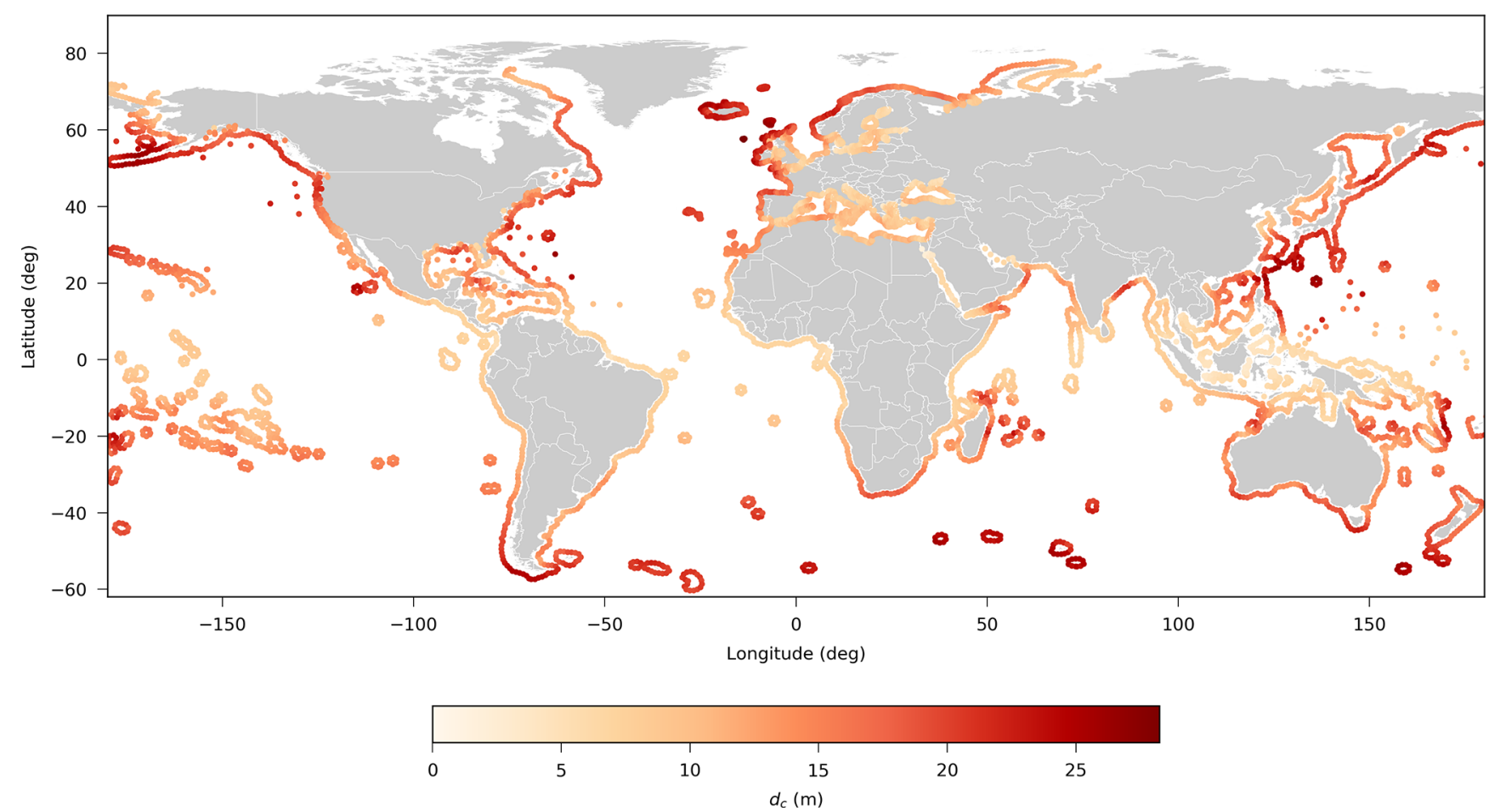

Figure 2. Depths of closure $d_{\mathrm{c}}$ along the global coastline using the formulation by Nicholls et al. (1998) (Eq. 1).

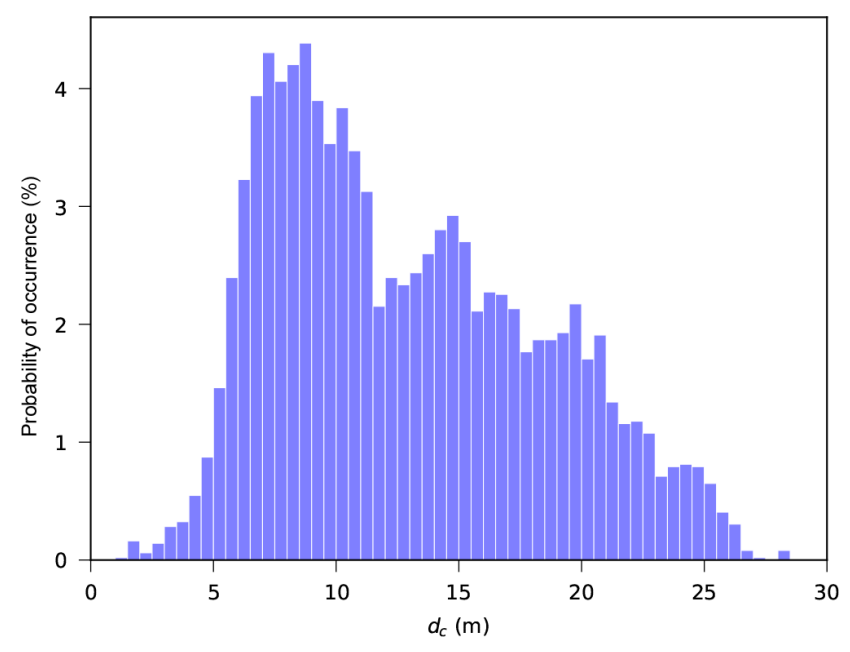

Figure 3. Histogram of the probability of occurrence of $d_{\mathrm{c}}$ globally (using bins of $0.5 \mathrm{~m}$ ).

northern Australia showing the highest and lowest variance, respectively.

\section{Comparison with local observations}

\subsection{Depth of closure}

Different methods exist to estimate the $d_{\mathrm{c}}$ and therefore the validation of this parameter can be quite challenging at a global scale. A thorough validation of the estimated depths of closure would demand various local bathymetrical surveys with good spatial resolution and sufficiently long temporal resolution and extent (i.e., 34 years of data). This kind of information is not readily available. Therefore, here we compare our results with a study at the US coast (Brutsché et al., 2016), which employed various formulas to calculate $d_{\mathrm{c}}$, including Eq. (1). We compared the $d_{\mathrm{c}}$ at the offshore locations of the US coast (Fig. 2) with the $d_{\mathrm{c}}$ of the closest point from Brutsché et al. (2016), calculated using the same formula (Eq. 1). Our predicted $d_{\mathrm{c}}$ showed skill in capturing the spatial variation as calculated by Brutsché et al. (2016) (Fig. S9), but presented a positive bias of $3.34 \mathrm{~m}$ (Fig. S10). This can be attributed to the different location and temporal scale of the wave statistics (i.e., Brutsché et al. (2016) used nearshore transformed wave time series of a 20 -year hindcast).

\subsection{Nearshore slopes}

The computed slopes were validated both qualitatively and quantitatively. The former was performed regionally using coastal classifications of the European and the Mediter- 

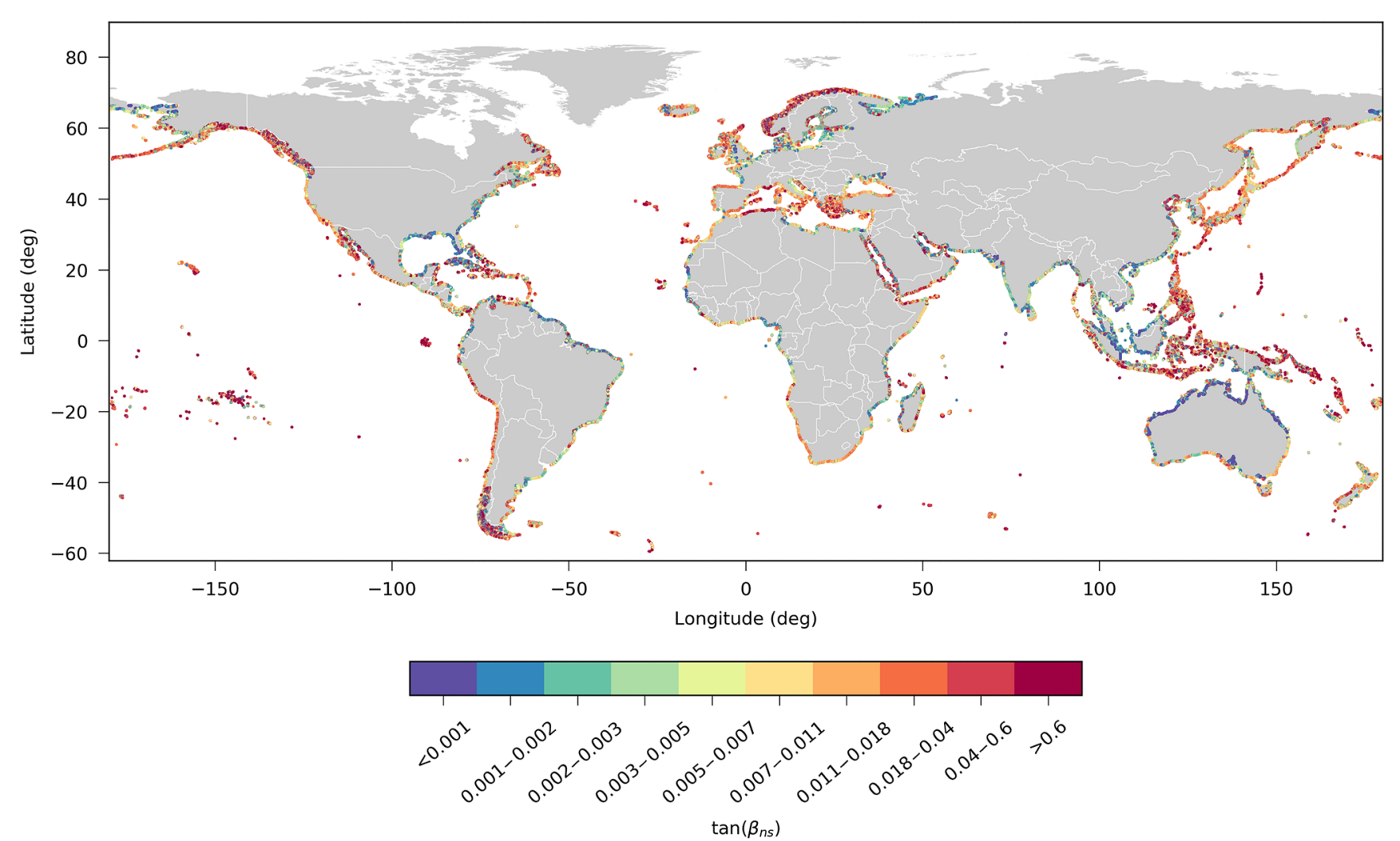

Figure 4. Global map of nearshore slopes. Red colors indicate steeper slopes while blue colors indicate milder slopes. Note that in the color scale the slopes have been grouped in non-equidistant increments in order to highlight the spatial differences.
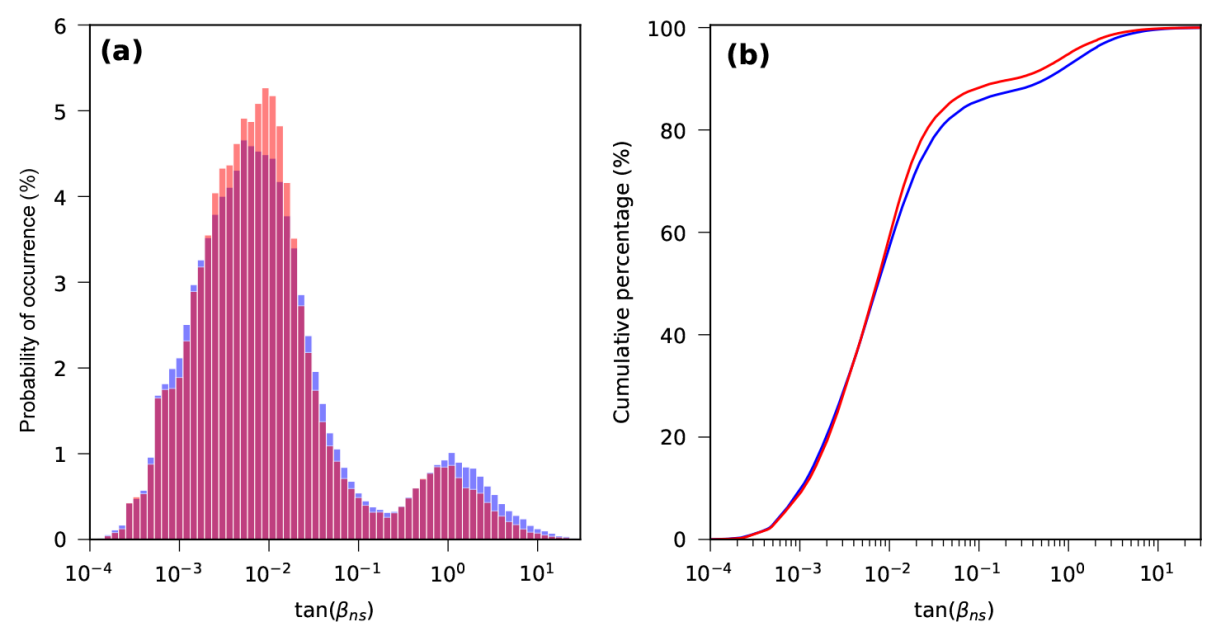

Figure 5. (a) Histogram of the probability of occurrence of nearshore slopes. (b) Cumulative probability distribution of nearshore slopes. The graphs have been plotted for all transects (blue) and only for sandy transects (red). Note that the $x$ axis is plotted on a log scale.

ranean coastlines, while the latter employed observations at sandy beaches derived from local surveys at eight study sites around the world.

\subsubsection{Qualitative validation}

Two coastal classification datasets were used to inspect the computed nearshore slopes grouped according to geomorphological coastal types. One was the Mediterranean coastal database (MCD) (Wolff et al., 2018), which classifies the Mediterranean coastline in four classes: (1) sandy beaches, 

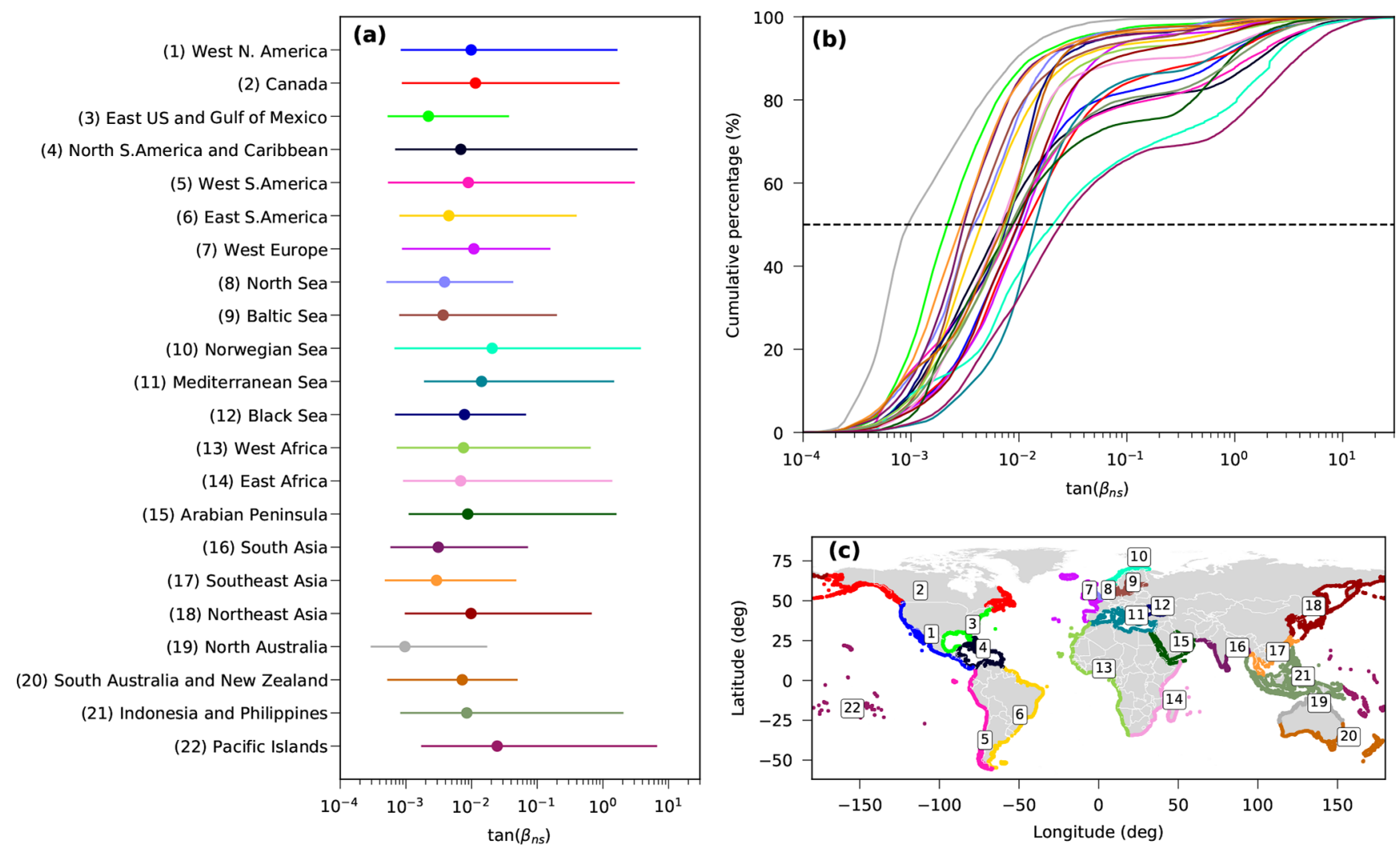

Figure 6. (a) Nearshore slope statistics per region. Dots indicate the median, while lines indicate the range between the 5th and 95th percentiles. (b) Cumulative probability distribution of nearshore slopes per region. Dashed line indicates the $50 \%$ line. (c) Global map with the defined regions with their respective color and ID. Note that (a) and (b) use the color scheme indicated by (c). The $x$ axis of (a) and (b) are plotted at a $\log$ scale.
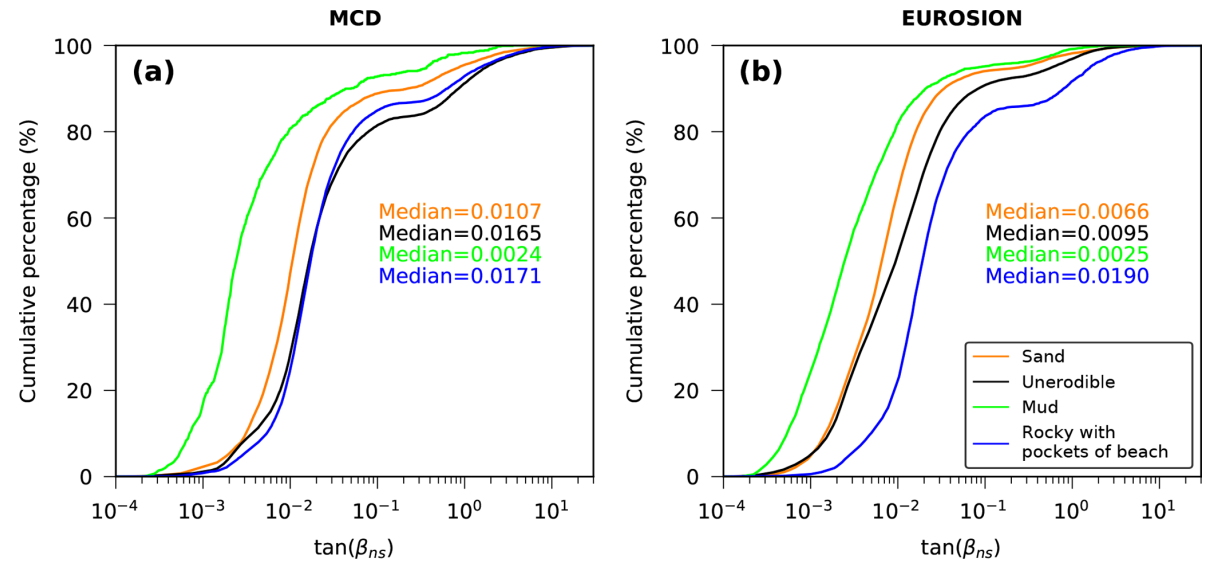

Figure 7. Cumulative probability distribution of nearshore slopes per coastal type for the (a) MCD dataset and (b) EUROSION dataset. The median values per coastal types are plotted with their respective colors as indicated in the legend. Note that the $x$ axis is plotted on a log scale.

(2) unerodible coasts, (3) muddy coastlines, and (4) rocky coasts with pocket beaches. The other was the EUROSION geomorphological classification (EUROSION, 2004) of the countries of the European Union (EU), which includes 20 different coastal types. The latter was reclassified to the four classes of the MCD database in order to reduce the total number of classes (Fig. S11)

The calculated nearshore slopes followed the expected variability between the different coastal typologies for both classification datasets (Fig. 7). For example, muddy coast- 


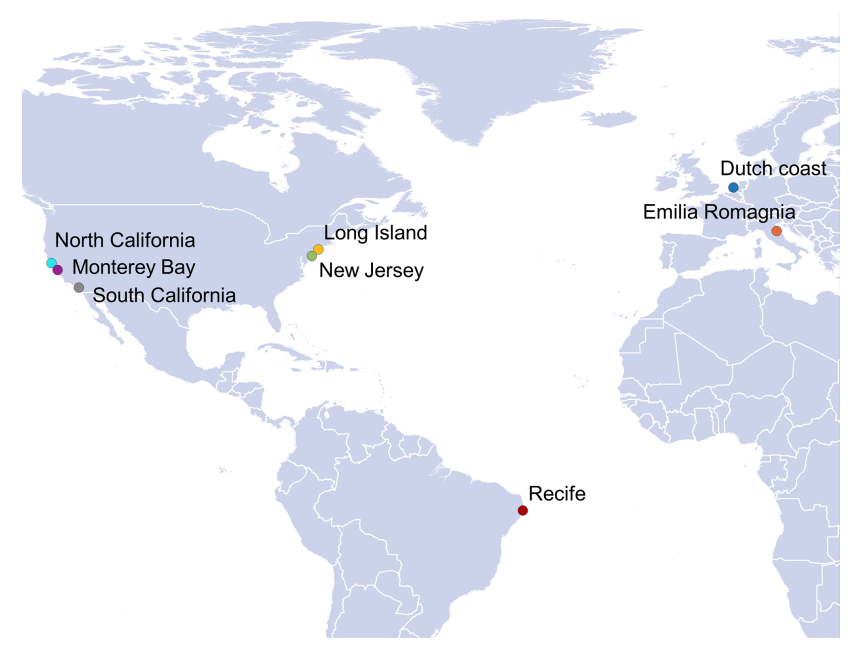

Figure 8. Field sites used for validation of the estimated global nearshore slopes.

lines had relatively milder nearshore slopes (median values of 0.0024 and 0.0025 for MCD and EUROSION datasets, respectively). Sandy coastlines had a median nearshore slope of 0.0107 and 0.0066 , respectively, for the MCD and EUROSION datasets, which relates to the steeper sandy beach slopes observed along the Mediterranean coastline. Unerodible and rocky coastlines had on average relatively steeper slopes.

\subsubsection{Quantitative validation}

The study sites for the quantitative validation were selected according to data availability and a criterion of having at least 20 transects overlapping with the derived global dataset to enable the computation of error statistics per site. The validation focused only on sandy coastline transects that are not adjacent to morphologically complex areas (e.g., inlets, river mouths) determined using satellite imagery. The ground truth sites (Fig. 8; Table 1) represent different coastal geomorphologies with varying hydrodynamic forcing and span across different continents. We performed the validation on the basis of the nearshore slopes, using the $d_{\mathrm{c}}$ values that were derived from the global analysis of wave data described in Sect. 2.2.2, for both local and global nearshore slope estimation. The local nearshore slope was calculated using the methodology described in Sect. 2.3.

When the elevation was represented by locally defined profiles, the comparison was performed using the closest globally derived transect. When point cloud data were available, they were first interpolated on a common grid and then the elevation was extracted along the global transects. The same process was performed when an elevation raster was available.

For a quantitative evaluation of the accuracy of the globally predicted slope values against the locally observed ones,

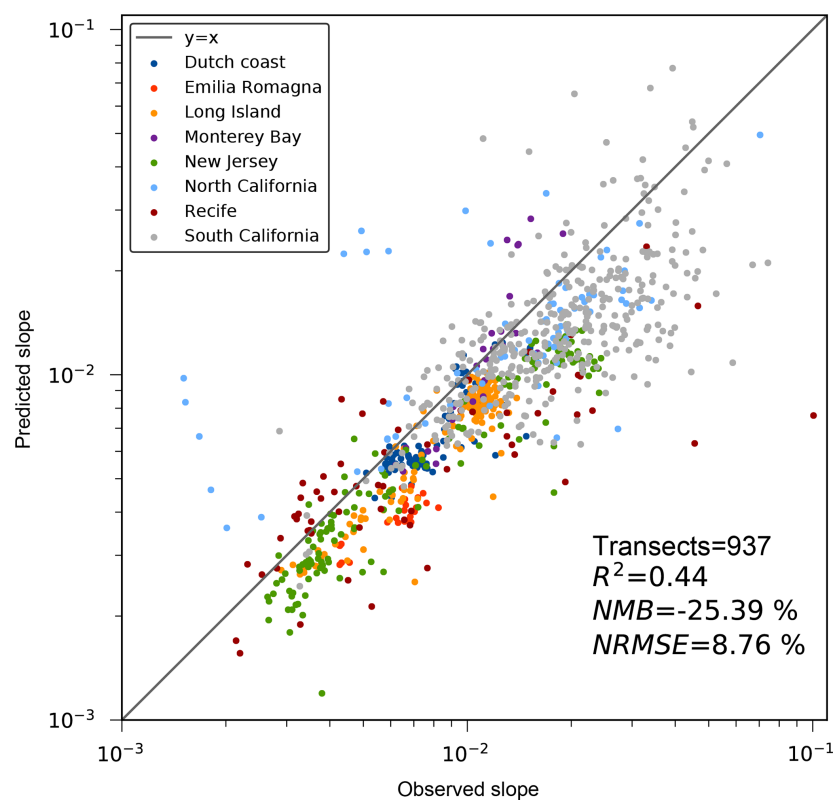

Figure 9. Linear regression between globally predicted nearshore slopes and nearshore slopes observed from local data for all study sites. Note that both axes are on a log scale.

various statistical parameters were calculated per site, as well as globally. This included the coefficient of determination $R^{2}$, the normalized mean bias (NMB) and the normalized root-mean-square error (NRMSE). Note that there is no temporal coherence between the predicted and observed data since the global elevation dataset is a merged product from temporally varying bathymetric sources (see Sect. 2.2.1) and the observed data were taken at different times. Therefore, it is expected that part of the calculated errors are due to potential temporal differences of the estimated and observed elevation data.

A regression analysis performed over all of the available global observations resulted in a normalized mean bias of almost $-25 \%$ and an $R^{2}$ value of 0.44 (Fig. 9), implying that extracted nearshore slopes captured the spatial variability of the ground truth data. The negative overall bias indicated that the calculated global slopes were on average milder than those observed.

The error statistics per validation site (Table 2) showed that overall, $R^{2}$ values were above 0.6 except for northern California, Recife, and southern California where poorer agreement was found (i.e., $0.38,0.25$, and 0.3 , respectively). At all validation sites (except Monterey Bay) a negative bias was observed. The NRMSE varied per study site, with values lower than $35 \%$ for five out of the eight validation sites. The high NRMSE at Emilia Romagna can be attributed to the quite high bias, but nevertheless the spatial variability was captured correctly $\left(R^{2}=0.7\right)$. It should be noted that the number of overlapping sandy transects differed significantly between sites as the spatial extent of the available local 
Table 1. Validation case study descriptions.

\begin{tabular}{|c|c|c|c|c|}
\hline Location (country) & Data format & Resolution & Year & Source \\
\hline $\begin{array}{l}\text { Dutch coast } \\
\text { (the Netherlands) }\end{array}$ & Elevation profiles & $\begin{array}{l}\text { Alongshore intervals of } \\
250 \mathrm{~m} \text { and cross-shore } \\
\text { resolution of } 5-10 \mathrm{~m}\end{array}$ & 2011 & Rijkswaterstaat (2018) \\
\hline $\begin{array}{l}\text { Emilia Romagna } \\
\text { (Italy) }\end{array}$ & Point cloud profiles & $\begin{array}{l}\text { Alongshore intervals of } \\
\sim 500 \mathrm{~m}\end{array}$ & 2012 & $\begin{array}{l}\text { Topo-bathymetric surveys of } \\
\text { beach profiles performed by } \\
\text { Arpae-SIMC in the context of } \\
\text { the regional topo-bathymetric } \\
\text { network }\end{array}$ \\
\hline $\begin{array}{l}\text { Northern California } \\
\text { (US) }\end{array}$ & Elevation profiles & $\begin{array}{l}\text { Alongshore intervals of } \\
100-200 \mathrm{~m} \text { and cross-shore } \\
\text { resolution of } 2 \mathrm{~m}\end{array}$ & $\begin{array}{l}\text { Various } \\
(1929-2017)\end{array}$ & Barnard et al. (2014) \\
\hline $\begin{array}{l}\text { Southern California } \\
\text { (US) }\end{array}$ & Elevation profiles & $\begin{array}{l}\text { Alongshore intervals of } \\
100-200 \mathrm{~m} \text { and cross-shore } \\
\text { resolution of } 2 \mathrm{~m}\end{array}$ & $\begin{array}{l}\text { Various } \\
(1930-2014)\end{array}$ & Barnard et al. (2014) \\
\hline Monterey (US) & Point cloud profiles & $\begin{array}{l}\text { Alongshore intervals of } \\
50-250 \mathrm{~m}\end{array}$ & 2017 & Stevens et al. (2017) \\
\hline Long Island (US) & Elevation raster & $1 / 9 \operatorname{arcsec}$ cell size & 2012 & $\begin{array}{l}\text { https://www.ngdc.noaa.gov/ } \\
\text { mgg/inundation/sandy/sandy_ } \\
\text { geoc.html (last access: } 10 \text { Oc- } \\
\text { tober } 2018 \text { ) }\end{array}$ \\
\hline New Jersey (US) & Elevation raster & $10 \mathrm{~m}$ cell size & $\begin{array}{l}\text { Various } \\
(1934-2013)\end{array}$ & Andrews et al. (2015) \\
\hline Recife (Brazil) & Point cloud profiles & $\begin{array}{l}\text { Alongshore intervals of } \\
\sim 150 \mathrm{~m}\end{array}$ & $\begin{array}{l}\text { Various } \\
(2012-2015)\end{array}$ & Vousdoukas et al. (2018a) \\
\hline
\end{tabular}

Table 2. Error statistics per validation site on the basis of the nearshore slopes $\tan \left(\beta_{\mathrm{ns}}\right)$.

\begin{tabular}{lrcrrr}
\hline Validation site & Transects & Mean observed nearshore slope & NMB (\%) & NRMSE (\%) & $R^{2}$ \\
\hline Dutch coast & 83 & 0.0083 & -18.0 & 24.4 & 0.62 \\
Emilia Romagna & 25 & 0.0062 & -62.6 & 130.4 & 0.70 \\
Long Island & 139 & 0.0092 & -31.4 & 33.3 & 0.80 \\
Monterey Bay & 27 & 0.0113 & 10.0 & 20.6 & 0.68 \\
New Jersey & 148 & 0.0100 & -53.8 & 40.1 & 0.87 \\
North California & 71 & 0.0156 & -11.2 & 18.4 & 0.38 \\
Recife & 62 & 0.0108 & -83.6 & 65.0 & 0.25 \\
South California & 382 & 0.0204 & -35.7 & 14.8 & 0.30 \\
\hline
\end{tabular}

surveys differed. For example, at Emilia Romagna and Monterey Bay there were only 25 and 27 overlapping transects, while at southern California there were 382 .

\section{Discussion}

\subsection{Spatial variation in nearshore slopes}

As discussed in the previous section the results of the present study revealed a quite pronounced spatial variation in nearshore slopes worldwide (Fig. 4). For example, the west coast of North and South America had on average steeper slopes in comparison to the east, which can be attributed to the swell-dominated wave climate along the former (the 
same holds for the west and east coasts of Africa). The classification of the coasts with respect to the plate tectonics (Inman and Nordstrom, 1971) seems to be relevant to nearshore slope distribution as well. Trailing edge coast with wider continental shelf width (e.g., North Sea, east coast of North and South America, North Australia) appeared to have milder nearshore slopes than leading edge coasts (e.g., west coast of North and South America and the biggest part of the Mediterranean). Sediment grain size can play an important role as well in the shape and slope of the nearshore profile (Dean, 1991). The coasts of the Gulf of Mexico and South and Southeast Asia showed on average mild nearshore slopes, which can be attributed to the large (historic) sediment supplies by some major rivers therein. The local slope values are ultimately the results of the combination of all the physical processes mentioned previously. At sedimentary coasts the upper nearshore profile is mainly influenced by waves while the lower one is influenced by tectonics, sediment supply, or major storm events.

\subsection{Improvements in estimations of SLR-induced retreat of sandy coasts}

Similarly to the overall dataset (including non-sandy coasts), the subset of nearshore slopes of sandy coasts displays a considerable spatial variation, even though the commonly used $1: 100$ nearshore slope assumption (Hinkel et al., 2013) lies in the most probable range (Fig. 5). Using the Bruun rule (Bruun, 1962), we investigated the effect of applying the spatial variation in the nearshore slope on the estimation of shoreline retreat due to sea level rise, in comparison with applying a uniform 1:100 slope as commonly done for sandy beaches.

The Bruun rule is a simple two-dimensional mass conservation principle, which predicts a landward and upward response of sandy profiles as a response to SLR. It is expressed as (Bruun, 1962)

$R=\frac{L}{d_{\mathrm{c}}} S$,

where $R$ is the horizontal coastal recession, $d_{\mathrm{c}}$ is the depth of closure, $L$ is the horizontal length from the shoreline to the depth of closure, and $S$ is the SLR. While used extensively for lack of a more efficient method, its use has been a controversial matter in literature during the last years (Cooper and Pilkey, 2004; Ranasinghe and Stive, 2009), as it is based on a number of assumptions and simplifications (i.e., equilibrium profile existence, cross-shore sediment balance). Nevertheless it is the only method that can deal with coastal recession due to SLR at a large scale in a computationally feasible manner. Since $\tan \left(\beta_{\mathrm{ns}}\right)=\frac{d_{\mathrm{c}}}{L}$ this makes Eq. (2)

$R=\frac{1}{\tan \left(\beta_{\mathrm{ns}}\right)} S$.
Physically, there are limits of the nearshore slopes that can be encountered at sandy beaches related to the angle of repose of granular materials. For our dataset, the sandy transects (Luijendijk et al., 2018) were found to lie beyond these ranges in some cases. This can be attributed to local effects of geology and sediment budget but also to data and methodological artefacts. Therefore, we applied upper and lower limits of 0.2 and 0.001 for the sandy nearshore slopes and constrained the slopes that lie beyond these limits to the limit values.

Following the linear relationship between the coastal recession $R$ and the nearshore slope in Eq. (3), the differences in the coastal recession under a given SLR scenario can show significant spatial variations. In order to highlight this, the ratio between the coastal recession $R_{\text {calc }}$ (i.e., using the nearshore slopes presented herein) and $R_{100}$ (i.e., using a $1 / 100$ nearshore slope globally) was estimated globally for all sandy transects (Fig. 10). The results indicate that for a large number of areas around the world the assumption of $1: 100$ nearshore slopes underestimates the potential coastal recession with a median $\frac{R_{\text {calc }}}{R_{100}}$ of 1.39 . However, it should be noted that there are also several locations with steeper slopes, where the $1: 100$ assumption overestimates the SLR-induced erosion.

In order to highlight the potential impact of this effect, a coastal recession estimate was computed for all transects of each region (see Fig. 6) using Eq. (3) for an arbitrary SLR of $0.5 \mathrm{~m}$ across the global coastline. The median value of the coastal recession of all transects per region was calculated as a robust description of its central tendency (Fig. 11) and compared with the value of $50 \mathrm{~m}$ (which is the recession that would be calculated for a SLR of $0.5 \mathrm{~m}$ using the $1: 100$ slope assumption). The results show that, in most of the defined regions the assumption of a 1:100 nearshore slope would result in the underestimation of coastal recession, especially in northern Australia, South and Southeast Asia, and the eastern US and Gulf of Mexico regions. However in some of the regions, such as the Mediterranean and Norwegian seas and the west coast of North and South America, the 1:100 slope assumption would lead to an overestimation due to the steeper nearshore slopes encountered on average there.

\subsection{Limitations}

The global scale of the present work introduced inevitable limitations related to data availability, computational efficiency, and methodological constraints. Merging bathymetric and topographic data at a global scale can be quite challenging. This is associated with differences in spatial resolution and potential overlaps or differences in the vertical datum. Here we tried to resolve these issues by using the OSM coastline as the MSL to differentiate between sea and land and connect the elevation data. Although other available coastline datasets exist, either they have a coarser resolution, therefore not allowing for a correct representation of the separation be- 

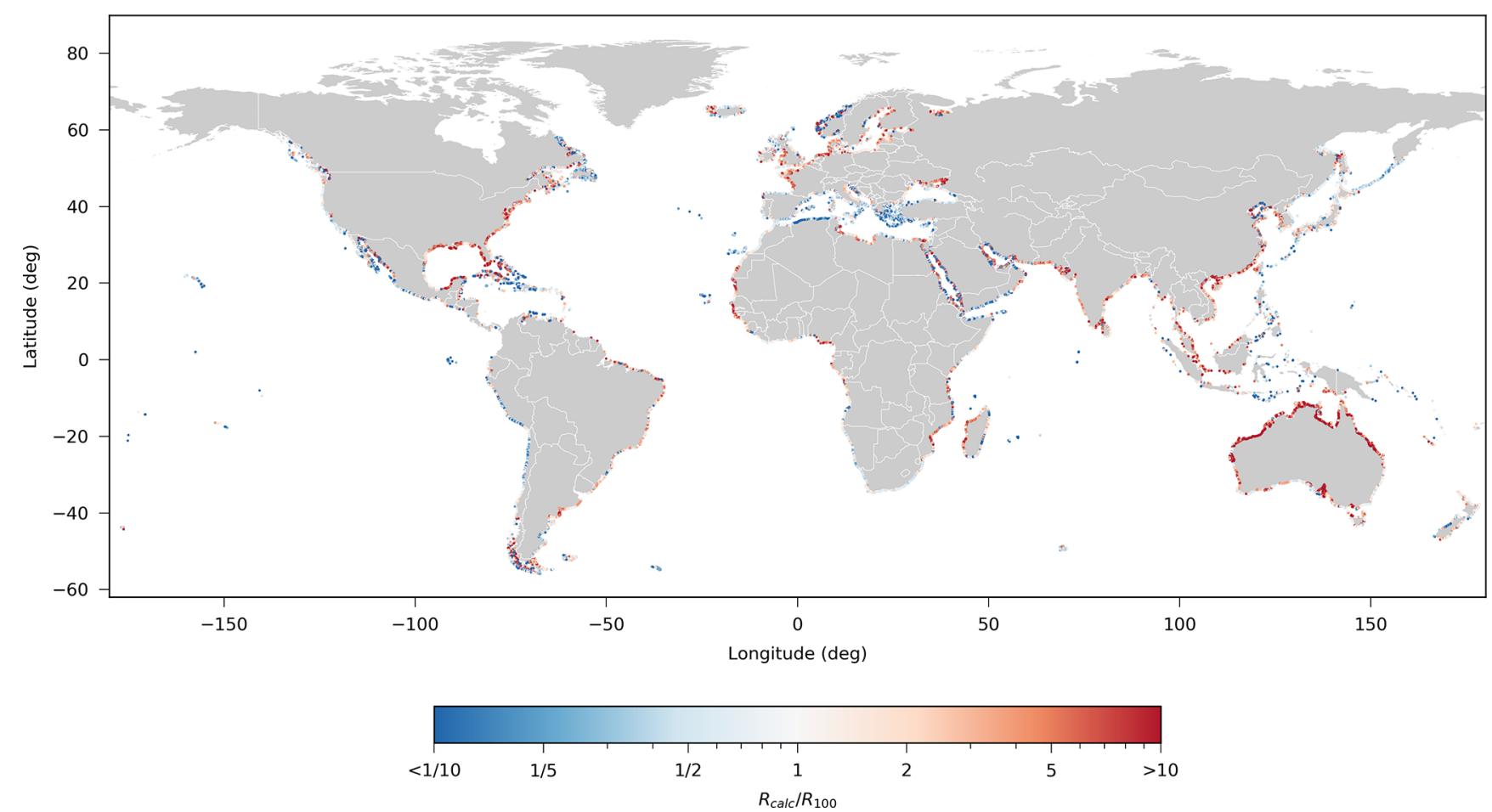

Figure 10. Global map of $\frac{R_{\text {calc }}}{R_{100}}$ where red colors indicate locations where the $\tan \left(\beta_{\mathrm{sf}}\right)=1: 100$ assumption underestimates the coastal recession while blue colors indicate locations where it overestimates it. Note that the color bar uses a log scale.

tween land and water, or they do not have a global coverage. The importance of the coastline and DEM data has been previously highlighted with respect to statistics of exposure information (Lichter et al., 2011). We expect that the choice of the coastline can have an effect in the elevation profiles, especially in areas with a high tidal range.

Additionally, GEBCO is a combination of bathymetric data derived from variable sources and different techniques and in some cases might have differences in the vertical datum (Weatherall et al., 2015). This might introduce regional differences in the trustworthiness of the results. The smoothing procedure that was applied to the bathymetric and topographic data may have affected the nearshore slope values, especially at cliffed coastlines, where the computed slopes may be milder than the reality. Nevertheless, cliffed transects retained quite steep values as can be seen by the second peak in the global slope distribution (Fig. 5). Furthermore, we expect that at locations where the nearshore slopes are steep, the resolution of the bathymetry is not high enough to capture a large number of bathymetry points between the shoreline and the depth of closure, hiding the details of the profile. We believe that when bathymetrical datasets with better resolution and accuracy become available in the future, the presented technique can be applied to update the global nearshore slope estimations.

The wave statistics that were used to determine the depth of closure across the global transects of the present study were taken from the closest offshore point of the wave reanalysis output (see Sect. 2.3). Ideally, the wave time series of the 28 years used here should be transformed to nearshore conditions at a location just offshore of the depth of closure using Snell's law. This would require an assumption of a nearshore slope, then the calculation of $d_{\mathrm{c}}$, and then the recalculation of the nearshore slope using an iterative approach until the slopes converge. This was deemed to be outside the scope of this study, considering the large number of transects. Nevertheless, we found that the nearshore slopes were not very sensitive to small changes in the depth of closure.

With respect to the comparison of the dataset compiled in the present study with available observations (Sect. 4), it should be mentioned that due to the scale of the study, it is quite challenging to perform a direct validation with the same spatiotemporal conditions. For example the comparison of the estimated $d_{\mathrm{c}}$ was performed against the results of a study that used the same formula, but employing wave statistics with different temporal extent and at different locations (Sect. 4.1). Additionally, the local surveys used for the quantitative comparison of the nearshore slopes had various sources, used different measuring techniques, and were collected at different times (Sect. 4.2.2). Naturally, it is expected that these spatiotemporal differences had an impact on the error statistics computed herein. More long-term coastal profile datasets, including coastal sites in diverse coastal environments, are needed to ensure a thorough validation of 


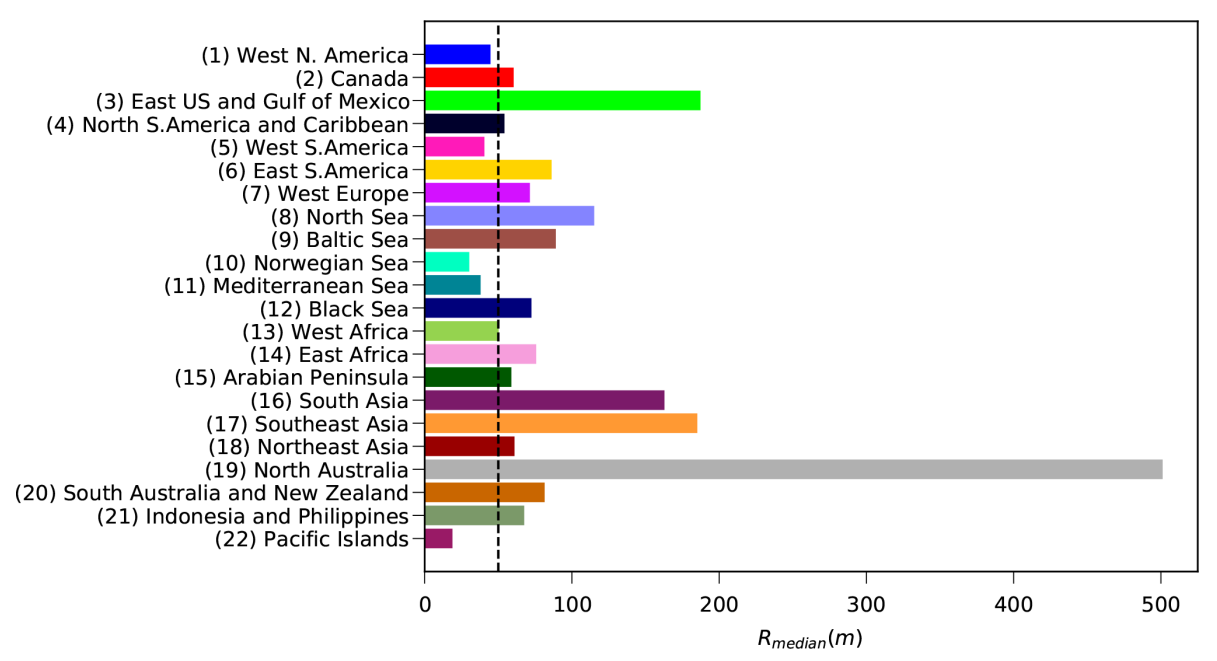

Figure 11. Median coastal recession in meters, calculated per region for the sandy transects assuming $0.5 \mathrm{~m}$ of SLR across the global coastline. The vertical dashed line indicates the recession of $50 \mathrm{~m}$, which would be the result if a 1/100 nearshore slope was assumed.

our dataset. The wealth of long-term satellite data combined with the constantly evolving remote sensing techniques can potentially be an avenue to consider in the future.

In this study the nearshore slope was defined from the depth of closure until the shoreline. This could be a deviation from certain Bruun rule implementations that define the active profile slope from the depth of closure until the dune or berm crest (Zhang et al., 2004; Hinkel et al., 2013; Toimil et al., 2017; Udo and Takeda, 2017). Given that the available global topographic datasets lack the resolution to resolve dunes or berms (Vousdoukas et al., 2018b), their inclusion in the analysis was not feasible, potentially resulting in an underestimation of the active profile slope (from the depth of closure to the top of the dune) along beaches with prominent dune systems. Nevertheless, since our dataset includes the nearshore slope and the depth of closure, one could calculate the slope from depth of closure to the dune or berm height if this information is available locally.

Another important matter is the sensitivity of the estimated nearshore slopes to the depth of closure values used in this study. In order to test the robustness of our dataset, and how different wave statistics or depth of closure formulae could affect our estimations, we varied the previously calculated $d_{\mathrm{c}}$ values (Sect. 2.3). Changes of $-20 \%,-10 \%, 10 \%$, and $20 \%$ of the originally estimated $d_{\mathrm{c}}$ were tested. The normalized differences of the estimated nearshore slopes had moderate sensitivity to the depth of closure variation (Fig. S12). When the depth of closure was increased and decreased by $10 \%$, at almost $70 \%$ of the transects, the nearshore slope changed by the same percentage. On the other hand, with an increase and decrease in the $d_{\mathrm{c}}$ by $20 \%$, the nearshore slope difference was on the order of $20 \%$ at about $75 \%$ of the transects. The number of transects with changes up to $20 \%$ was higher when only the sandy transects were considered. In general, the largest increase in the nearshore slope was observed when $d_{\mathrm{c}}$ was decreased. The spatial distribution of the relative nearshore slope changes showed that in most cases the sensitivity was low. The most sensitive areas to changes in $d_{\mathrm{c}}$ were areas with steep slopes (e.g., fjord areas in Norway, Chile, and others) (Fig. S13).

\section{Data availability}

The final output data provide the location of each of the $\sim 780000$ points along the global coastline together with (a) the depth of closure $d_{\mathrm{c}}$, (b) the nearshore slope $\tan \left(\beta_{\mathrm{ns}}\right)$ and (c) an error/warning code in case the slope was not calculated or limitations in the profile were spotted. These data are given as a comma-separated value file. The data can be downloaded via https://doi.org/10.4121/uuid:a8297dcdc34e-4e6d-bf66-9fb8913d983d (Athanasiou, 2019).

\section{Conclusions}

A dataset of the global distribution of nearshore slopes at an alongshore resolution of $1 \mathrm{~km}$ is presented, using global elevation datasets and wave statistics. Depths of closure $d_{\mathrm{c}}$ were estimated worldwide using an empirical formulation and long-term wave statistics derived from 34-year wave reanalysis. The average $d_{\mathrm{c}}$ globally was almost $13 \mathrm{~m}$, attaining larger values at higher latitudes. The global median nearshore slope was 0.007 , while most values were in the range 0.001 to 0.565 (10th and 90th percentiles, respectively). The most commonly computed nearshore slope was about 0.005 , which increased to 0.01 when only sandy coasts were considered. However, the computed nearshore slopes exhibited substantial spatial variability, potentially corresponding with spatial variations in hydrodynamic forcing and geological conditions. 
The dataset captured expected qualitative nearshore slope patterns when compared to available coastal classification datasets. Additionally, it captured the spatial variability of the nearshore slopes of sandy beaches at eight validation sites from around the world, but with a negative bias of $25 \%$ (milder slopes than the observed ones).

The assessment of SLR-driven coastline recession (for an arbitrary $0.5 \mathrm{~m} \mathrm{SLR}$ ) with globally uniform coastal slopes, as performed in many previous studies, and the spatially variable nearshore slopes computed herein showed large differences between the recession amounts projected by the two approaches. Worldwide, the median coastline recession calculated with the nearshore slopes computed here was almost $40 \%$ larger than that computed by assuming a globally uniform $1: 100$ coastal slope, with the ratio between the two estimates varying substantially around the world. We believe that this dataset is a first step towards capturing the spatial variability of coastal profile characteristics and enabling a correct spatial representation of coastal impacts.

Supplement. The supplement related to this article is available online at: https://doi.org/10.5194/essd-11-1515-2019-supplement.

Author contributions. PA, AvD, AG, MV, and RR designed the study. PA carried out the data processing and analysis. MV provided the offshore wave statistics. SGA composed the merged topobathymetric dataset. PA prepared the paper with contributions from all co-authors.

Competing interests. The authors declare that they have no conflict of interest.

Acknowledgements. Ap van Dongeren was funded in part by the Deltares strategic research program "Quantifying Flood Hazards and Impacts" and Alessio Giardino from the research program "Flood Risk Strategies". Roshanka Ranasinghe is supported by the AXA Research Fund and the Deltares strategic research program "Coastal and Offshore Engineering". We would like to acknowledge Arjen Luijendijk for providing the location of the sandy transects from their study. We would also like to acknowledge the OpenStreetMap contributors for use of the map data available from https://www.openstreetmap.org (last access: 22 February 2018).

Financial support. This work has received funding from the EU Horizon 2020 Programme for Research and Innovation, under grant agreement no. 776613 (EUCP: EUropean Climate Prediction system; https://www.eucp-project.eu, last access: 5 May 2019).

Review statement. This paper was edited by Dirk Fleischer and reviewed by two anonymous referees.

\section{References}

Andrews, B. D., Defne, Z., Miselis, J. L., and Ganju, N. K.: Continuous terrain model for water circulation studies, Barnegat Bay, New Jersey, US Geological Survey data release, https://doi.org/10.5066/F7PK0D6B, 2015.

Antolínez, J. A. A., Murray, A. B., Méndez, F. J., Moore, L. J., Farley, G., and Wood, J.: Downscaling Changing Coastlines in a Changing Climate: The Hybrid Approach, J. Geophys. Res.Earth, 123, 229-251, https://doi.org/10.1002/2017JF004367, 2018.

Athanasiou, P.: Global distribution of nearshore slopes, 4TU.Centre Res. Data, https://doi.org/10.4121/uuid:a8297dcd-c34e-4e6dbf66-9fb8913d983d, 2019.

Ballesteros, C., Jiménez, J. A., Valdemoro, H. I., and Bosom, E.: Erosion consequences on beach functions along the Maresme coast (NW Mediterranean, Spain), Nat. Hazards, 90, 173-195, https://doi.org/10.1007/s11069-017-3038-5, 2018.

Barnard, P. L., van Ormondt, M., Erikson, L. H., Eshleman, J., Hapke, C., Ruggiero, P., Adams, P. N., and Foxgrover, A. C.: Development of the Coastal Storm Modeling System $(\mathrm{CoSMoS})$ for predicting the impact of storms on highenergy, active-margin coasts, Nat. Hazards, 74, 1095-1125, https://doi.org/10.1007/s11069-014-1236-y, 2014.

Baron, H. M., Ruggiero, P., Wood, N. J., Harris, E. L., Allan, J., Komar, P. D., and Corcoran, P.: Incorporating climate change and morphological uncertainty into coastal change hazard assessments, Nat. Hazards, 75, 2081-2102, https://doi.org/10.1007/s11069-014-1417-8, 2014.

Battjes, J. A.: Surf similarity, in: Coastal Engineering Proceedings, vol. 1, p. 26, 1974.

Birkemeier, W. A.: Field Data on Seaward Limit of Profile Change, J. Waterw. Port, Coastal, Ocean Eng., 111, 598602, https://doi.org/10.1061/(asce)0733-950x(1985)111:3(598), 1985.

Brutsché, K. E., Rosati III J., Pollock C. E., and McFall B. C.: Calculating depth of closure using WIS hindcast data, ERDC/CHL CHETN-VI-45. Vicksburg, MS, U.S. Army Engineer Research and Development Center, 2016.

Bruun, P.: Sea-Level Rise as a Cause of Shore Erosion, J. Waterw. Harb. Div., 88, 117-132, 1962.

Cooper, J. A. G. and Pilkey, O. H.: Sea-level rise and shoreline retreat: Time to abandon the Bruun Rule, Global Planet. Change, 43, 157-171, https://doi.org/10.1016/j.gloplacha.2004.07.001, 2004.

Dean, R. G.: Equilibrium Beach Profiles?: Characteristics and Applications, J. Coast. Res., 7, 53-84, 1991.

EUROSION: Living with coastal erosion in Europe: Sediment and Space for Sustainability: PART I - Major findings and Policy Recommendations of the EUROSION project, European Commission, 2004.

Farr, T. G., Rosen, P. A., Caro, E., Crippen, R., Duren, R., Hensley, S., Kobrick, M., Paller, M., Rodriguez, E., Roth, L., Seal, D., Shaffer, S., Shimada, J., Umland, J., Werner, M., Oskin, M., Burbank, D., and Alsdorf, D. E.: The shuttle radar topography mission, Rev. Geophys., 45, RG2004, https://doi.org/10.1029/2005RG000183, 2007.

Giardino, A., Schrijvershof, R., Nederhoff, C. M., de Vroeg, H., Brière, C., Tonnon, P. K., Caires, S., Walstra, D. J., Sosa, J., van 
Verseveld, W., Schellekens, J., and Sloff, C. J.: A quantitative assessment of human interventions and climate change on the West African sediment budget, Ocean Coast. Manag., 156, 249265, https://doi.org/10.1016/j.ocecoaman.2017.11.008, 2018a.

Giardino, A., Nederhoff, C., and Vousdoukas, M. I.: Coastal hazard risk assessment for small islands: assessing the impact of climate change and disaster reduction measures on Ebeye (Marshall Islands), J. Reg. Environ. Change, 18, 2237-2248, 2018 b.

Hallermeier, R. J.: Uses for a calculated limit depth to beach erosion, Coast. Eng., 88, 1493-1512, 1978.

Hanson, H.: Genesis: A Generalized Shoreline Change Numerical Model, J. Coast. Res., 5, 1-27, 2014.

Hinkel, J., Nicholls, R. J., Tol, R. S. J., Wang, Z. B., Hamilton, J. M., Boot, G., Vafeidis, A. T., McFadden, L., Ganopolski, A., and Klein, R. J. T.: A global analysis of erosion of sandy beaches and sea-level rise: An application of DIVA, Global Planet. Change, 111, 150-158, https://doi.org/10.1016/j.gloplacha.2013.09.002, 2013.

Inman, D. L. and Nordstrom, C. E.: On the Tectonic and Morphologic Classification of Coasts, J. Geol., 79, 1-21, https://doi.org/10.1086/627583, 1971.

Larson, M., Erikson, L., and Hanson, H.: An analytical model to predict dune erosion due to wave impact, Coast. Eng., 51, 675696, https://doi.org/10.1016/j.coastaleng.2004.07.003, 2004.

Lichter, M., Vafeidis, A. T., and Nicholls, R. J.: Exploring DataRelated Uncertainties in Analyses of Land Area and Population in the "Low-Elevation Coastal Zone" (LECZ), J. Coast. Res., 27, 757-768, https://doi.org/10.2112/jcoastres-d-10-00072.1, 2011.

Luijendijk, A., Hagenaars, G., Ranasinghe, R., Baart, F., Donchyts, G., and Aarninkhof, S.: The State of the World's Beaches, Sci. Rep., 1-11, https://doi.org/10.1038/s41598-018-24630-6, 2018.

McCall, R. T., Van Thiel de Vries, J. S. M., Plant, N. G., Van Dongeren, A. R., Roelvink, J. A., Thompson, D. M., and Reniers, A. J. H. M.: Two-dimensional time dependent hurricane overwash and erosion modeling at Santa Rosa Island, Coast. Eng., 57, 668683, https://doi.org/10.1016/j.coastaleng.2010.02.006, 2010.

McGranahan, G., Balk, D., and Anderson, B.: The rising tide: Assessing the risks of climate change and human settlements in low elevation coastal zones, Environ. Urban., 19, 17-37, https://doi.org/10.1177/0956247807076960, 2007.

Melet, A., Meyssignac, B., Almar, R., and Le Cozannet, G.: Underestimated wave contribution to coastal sea-level rise, Nat. Clim. Change, 8, 234-239, https://doi.org/10.1038/s41558-018-0088y, 2018.

Mentaschi, L., Vousdoukas, M. I., Pekel, J. F., Voukouvalas, E., and Feyen, L.: Global long-term observations of coastal erosion and accretion, Sci. Rep., 8, 1-11, https://doi.org/10.1038/s41598018-30904-w, 2018.

Monioudi, I. N., Velegrakis, A. F., Chatzipavlis, A. E., Rigos, A., Karambas, T., Vousdoukas, M. I., Hasiotis, T., Koukourouvli, N., Peduzzi, P., Manoutsoglou, E., Poulos, S. E., and Collins, M. B.: Assessment of island beach erosion due to sea level rise: the case of the Aegean archipelago (Eastern Mediterranean), Nat. Hazards Earth Syst. Sci., 17, 449-466, https://doi.org/10.5194/nhess17-449-2017, 2017.

Neumann, B., Vafeidis, A. T., Zimmermann, J.. and Nicholls, R. J.: Future coastal population growth and exposure to sea-level rise and coastal flooding - A global assessment, PLoS One, 10, e0118571, https://doi.org/10.1371/journal.pone.0118571, 2015.
Nicholls, R. J., Birkemeier, W. A., and Lee, G.: Evaluation of depth of closure using data from Duck, NC, USA, Mar. Geol., 148, 179-201, 1998.

OpenStreetMap contributors: OSM coastline, available at: https:// planet.osm.org (last access: 22 February 2018), 2015.

Ranasinghe, R. and Stive, M. J. F.: Rising seas and retreating coastlines, Clim. Change, 97, 465-468, https://doi.org/10.1007/s10584-009-9593-3, 2009.

Rijkswaterstaat: Jarkus cross-shore profile measurements database, available at: https://publicwiki.deltares.nl/display/OET/Dataset+ documentation+JarKus, last access: 15 November 2018.

Ruggiero, P., Buijsman, M., Kaminsky, G. M., and Gelfenbaum, G.: Modeling the effects of wave climate and sediment supply variability on large-scale shoreline change, Mar. Geol., 273, 127140, https://doi.org/10.1016/j.margeo.2010.02.008, 2010.

Serafin, K. A., Ruggiero, P., Barnard, P. L., and Stockdon, H.: The influence of shelf bathymetry and beach topography on extreme total water levels: Linking large-scale changes of the wave climate to local coastal hazards, Coast. Eng., 150, 1-17, https://doi.org/10.1016/j.coastaleng.2019.03.012, 2019.

Stevens, A. W., Logan, J. B., Snyder, A. G., Hoover, D. J., Barnard, P. L., and Warrick, J. A.: Beach topography and nearshore bathymetry of northern Monterey Bay, California, U.S. Geological Survey data release, https://doi.org/10.5066/F76H4GCW, 2017.

Tadono, T., Takaku, J., Tsutsui, K., Oda, F., and Nagai, H.: Status of "ALOS World 3D (AW3D)" global DSM generation, 2015 IEEE International Geoscience and Remote Sensing Symposium (IGARSS), Milan, Italy, 26-31 July 2015, 3822-3825, https://doi.org/10.1109/IGARSS.2015.7326657, 2015.

Toimil, A., Losada, I. J., Camus, P., and Díaz-Simal, P.: Managing coastal erosion under climate change at the regional scale, Coast. Eng., 128, 106-122, https://doi.org/10.1016/j.coastaleng.2017.08.004, 2017.

Udo, K. and Takeda, Y.: Projections of Future Beach Loss in Japan Due to Sea-Level Rise and Uncertainties in Projected Beach Loss, Coast. Eng. J., 59, 1740006, https://doi.org/10.1142/S057856341740006X, 2017.

Vousdoukas, M., Mentaschi, L., Voukouvalas, E., Kakoulaki, G., Pereira, P. S., Lino, A. P., and Feyen, L.: Assessing compound flooding risk through dynamic simulations: application in Recife, Brazil, Geophysical Research Abstracts, 20, EGU2018-2589, 2018a.

Vousdoukas, M. I., Mentaschi, L., Voukouvalas, E., Verlaan, M., and Feyen, L.: Extreme sea levels on the rise along Europe's coasts, Earths Future, 5, 304-323, https://doi.org/10.1002/2016EF000505, 2017.

Vousdoukas, M. I., Bouziotas, D., Giardino, A., Bouwer, L. M., Mentaschi, L., Voukouvalas, E., and Feyen, L.: Understanding epistemic uncertainty in large-scale coastal flood risk assessment for present and future climates, Nat. Hazards Earth Syst. Sci., 18, 2127-2142, https://doi.org/10.5194/nhess-18-2127-2018, 2018b.

Weatherall, P., Marks, K. M., Jakobsson, M., Schmitt, T., Tani, S., Arndt, J. E., Rovere, M., Chayes, D., Ferrini, V., and Wigley, R.: A new digital bathymetric model of the world's oceans, Earth Space Sci., 2, 331-345, https://doi.org/10.1002/2015EA000107, 2015.

Wolff, C., Vafeidis, A. T., Muis, S., Lincke, D., Satta, A., Lionello, P., Jimenez, J. A., Conte, D., and Hinkel, J.: A 
Mediterranean coastal database for assessing the impacts of sea-level rise and associated hazards, Sci. Data, 5, 180044, https://doi.org/10.1038/sdata.2018.44, 2018.

Wright, L. D. and Short, A. D.: Morphodynamic variability of surf zones and beaches: A synthesis, Mar. Geol., 56, 93-118, https://doi.org/10.1016/0025-3227(84)90008-2, 1984.

Yamazaki, D., Ikeshima, D., Tawatari, R., Yamaguchi, T., O'Loughlin, F., Neal, J. C., Sampson, C. C., Kanae, S., and Bates, P. D.: A high-accuracy map of global terrain elevations, Geophys. Res. Lett., 44, 5844-5853, https://doi.org/10.1002/2017GL072874, 2017.
Zhang, K. Q., Douglas, B. C., and Leatherman, S. P.: Global warming and coastal erosion, Clim. Change, 64, 41-58, https://doi.org/10.1023/b:clim.0000024690.32682.48, 2004. 